\title{
Tipología de los colorónimos en inglés y alemán en el discurso periodístico: aspecto semántico
}

\author{
Typology of English and German Coloronyms in Journalistic \\ Discourse: Semantic Aspect
}

\author{
Alla V. Oleksiienko ${ }^{1 a}$, Liliia V. Bespala ${ }^{2}$, Iryna L. Vovk ${ }^{3}$, Yuliia S. Vysotska ${ }^{4}$ \\ Zaporizhzhia State Medical University, Zaporizhzhia, Ukraine ${ }^{1234}$ \\ (iD) ORCID ID: https://orcid.org/0000-0002-8868-14901 \\ iD ORCID ID: https://orcid.org/0000-0002-6127-369X ${ }^{2}$ \\ iD ORCID ID: https://orcid.org/0000-0002-2998-765X ${ }^{3}$ \\ iD ORCID ID: https://orcid.org/0000-0002-2976-1562
}

Recibido: 09 de agosto de 2021

Aceptado: 20 de noviembre de 2021

\section{Resumen}

El artículo trata de un estudio exhaustivo de los colorónimos en inglés y alemán en textos periodísticos. El propósito del estudio es identificar las características semánticas de los colorónimos y su funcionamiento en el periodismo inglés y alemán. El procedimiento de estudiar los colorónimos en inglés y alemán en un texto periodístico se implementa a través de métodos de investigación lingüística, a saber: método etimológico, análisis de definiciones de diccionario, análisis semántico y análisis de contexto. Los resultados del estudio se presentan en la separación de campos asociativos y colorónimos en inglés y alemán, determinando la frecuencia de uso de colorónimos básicos en el discurso periodístico inglés y alemán. Se ha descubierto que los colorónimos reflejan cambios en la sociedad de habla inglesa y alemana, así como en el mundo en general. Asimismo, se encontró que las unidades para el mismo color en inglés y alemán pueden tener diferentes connotaciones.

Palabras clave: Color, colorónimo, significado connotativo, texto periodístico, unidad fraseológica, narrativa.

\begin{abstract}
The article deals with a comprehensive study of English and German coloronyms in journalistic texts. The purpose of the study is to identify the semantic features of coloronyms and their functioning in English and German journalism. The procedure of studying English and German coloronyms in a journalistic text is implemented through linguistic research methods, namely: etymological method, analysis of dictionary definitions, semantic analysis and the context analysis. The results of the study are presented in the separation of associative fields and coloronyms in English and German, determining the frequency of use of basic coloronyms in English and German journalistic discourse. Coloronyms have been found to reflect changes in
\end{abstract}


English-speaking and German-speaking society, as well as in the world as a whole. It was found that the units for the same color in English and German may have different connotations.

Keywords: Color, coloronym, connotative meaning, journalistic text, phraseological unit, narrative.

\section{Introduction}

A peculiar problem for scientific research in recent years has been the study of units for color designation in various fields. Some scholars consider coloronyms a universal phenomenon studied in anthropology (Witzel, O'Regan \& Rothen, 2016), psychology (Radonjić \& Brainard, 2016), philosophy (Spillmann, 2018), sociology (Scheurmann \& Karliczek, 2017), marketing (Nufer \& Wenk, 2017), computer graphics (Gramazio et al., 2017), other researchers insist that colouronyms are a cultural phenomenon only (Gage, 2011).

In domestic linguistics, such terms as color designation, color nomination, color names, color terms, coloratives are used to denote color (Herasymenko, 2012). In foreign linguistics, coloronyms are denoted by the terms color names (Kim et al., 2019), color terms (Davies, 2005), die Farbbezeichnungen (Boerboom \& Proetel, 2018), die Farbwörter (Magnus, 1980). In our study, we use the term "coloronym" interpreted as a token, the meaning of which is an attribute of color (Magnus, 1980).

Color as an anthropocentric substance is characterized by the ability to denote a wide range of material and ideal features and phenomena, a wealth of associative meanings and therefore continues to attract the attention of specialists in various fields of knowledge, including linguists. Scientists pay attention to a wide range of issues of linguistic mediation of color, among which the following can be distinguished: the history of the formation of color names and their development in diachrony (Kulpina, 2007; Normanskaya, 2005), national and cultural features of color designation in different languages (Vasilevich, 2007; Chernetska, 2018), linguistic aspects of the formation and functioning of color symbols (Vlasova, 2008; Serov, 2004), the semantic specificity of lexical units denoting color (Lukashenko, 2011; Antipova, 2020), cognitive aspects of color nominations (Talapina, 2008; Volkova, 2019), functioning phraseological units with color component in English media (Tikan \& Lopianetska, 2020), methods and peculiarities of translating (Holovanevska, 2018; Shaitan, 2018) and others.

Taking into account the color diversity of the surrounding world, it can be argued that the linguistic categorization of the color continuum presupposes, first of all, a solution to the problem of identifying basic and peripheral color categories. Basic color designations trends in the development of the vocabulary of color designations (based on the material of modern 
English with the involvement of research results of other languages) are prototypes or points of cognitive reference and have a special cognitive status - to be the best example of a category.

According to Berlin and Kay (1969), for any language the central stage in the development of the color designation system is the process of forming a "core" - a group of words that are called "basic color words". The allocation of a limited number of "basic" color lexemes for several dozen languages and their comparison allowed the authors to conclude that the formation of a group of basic color names is a long process, subject to quite definite universal laws. The analysis of these patterns is devoted to the classical monograph by Berlin and Kay (1969) "Basic Color Terms: Their Universality and Evolution". Since the characteristics of color perception, analysis of coloronyms in the texts of some languages attracted scholars' attention, there is a need to study the semantics of coloronyms in English and German-language journalistic texts to compare their typology and features of their functioning, which determines the topicality of our research.

The goal of the research at is to make clear the semantic functions of coloronyms in the journalism of English and German providing for fulfilment of the following objectives: arrange the categorical and conceptual apparatus of the study; to establish the evolution of coloronyms of English and German languages; analyze the semantic structure of coloronyms in English and German; determine the typological features of the functioning of coloronyms in journalistic discourse through the analysis of thematic groups.

\section{Methods}

More than 3000 phraseological units considered in the framework of the Englishlanguage and German-language media discourse. Data for studies were obtained by sampling from media material, according to categories of the presented directions, based on Englishspeaking and German-speaking periodicals for the period 2007-2017. To form a base the data of the etymological dictionary, phraseological dictionary were used Longman, Oxford Dictionary of English Idioms, Cambridge the international dictionary of idioms, as well as the A. V. Kunin English-Russian phraseological dictionary.

This technique includes a specific procedure, which involves the following stages: 1) studying the meanings of all words and expressions denoting color selected from English and German journalistic texts; 2) arrangement of selected coloronyms with regard to their semantics; 3) conducting a typological comparison of the studied units in English and German journalistic texts; The outlined procedure of our studies is primarily based totally at the complicated utility of linguistic methods and techniques for the analysis of English and German 
coloronyms, which allows establishing their semantic meaning, clarifying the functional characteristics of coloronyms in a journalistic text.

The method of continuous sampling is used to select the analysed units. The text fragments containing coloronyms and their phraseological derivatives are selected from the texts of journalistic texts and processed using this method. The material of our study was a body of news texts selected from the most popular English and German websites due to the popularity, prevalence and accessibility of Internet news for recipients, as well as the fact that the language of journalistic texts is modern and relevant.

The analysis of dictionary definitions allowed learning about the origin of the word, its initial sound and changes in meanings in the course of language development. Etymological analysis of the word was used to identify the original forms and meanings of coloronyms, as well as to determine historical changes in its original form and meaning that led to the emergence of modern form and meaning. Contextual analysis is aimed at establishing the peculiarities of the functioning of coloronyms in a particular linguistic act. Semantic analysis to identify the semantic structure of coloronyms was used. Thus, this paper used a comprehensive method of analysis that allows considering the phenomenon of ambiguity of color names as a dynamic system that stores and accumulates linguistic and cultural information, including the connotative meaning of universal, nation-specific and social nature.

\section{Results}

The study of English and German coloronyms from the point of view of the linguistic picture of the world is of particular interest because it allows understanding how native speakers of different languages perceive the world around them, as well as to see the difference in the use of certain language means. Let us consider the origin of the names of the main colors, the related associative fields, the change in color meaning depending on the language units with which the coloronym is associated, and finally, how the analysed units function in journalistic texts (see Table 1). 
Table 1

Comparison of associative fields and colouronyms in English and German

\begin{tabular}{ccc}
\hline Associative fields & English & German \\
\hline light & white & weiß \\
darkness & black & schwarz \\
fire & red, black & rot \\
nature & green, red & grün \\
joy & red & - \\
rest & white & - \\
good & white & weiß \\
anger & red, white (rarely) & grün, weiß \\
trouble, sorrow & black & schwarz \\
disease & green & grün, weiß \\
envy & green & grün \\
jealousy & green & grün \\
mysticism & white, black & weiß, schwarz \\
evil spirit & black, red & schwarz \\
illegality & black & schwarz \\
social status & white, black & weiß, schwarz \\
politics & red & grün, weiß \\
epidemic & red, green & rot, grün \\
\hline
\end{tabular}

The analysis of journalistic texts in the pictures of the world of English and German identified the coloronyms "black / schwarz", "white / weiß", "green / grün", "red/rot", "blue/blau", "brown / braun", "grey / grau” and "yellow / gelb”. However, the first four are the most used. It should be noted that these units for color designation change their primary meaning in journalistic texts in most cases.

Black / schwarz along with white deserve special attention in both English and German. According to the theory of Berlin and Kay (1969), these two colors appeared earlier than the others. People divided the color space into "light" and "dark", black was usually associated and is associated with evil, evil spirits. The study showed that the linguistic color picture of the world in English and German is quantitatively characterised by the predominance of black - macro color (black (English) and schwarz (German)) (See Figure 1 and Figure 2). Thus, this color is at the centre of the core of the color picture of the world of both languages. 


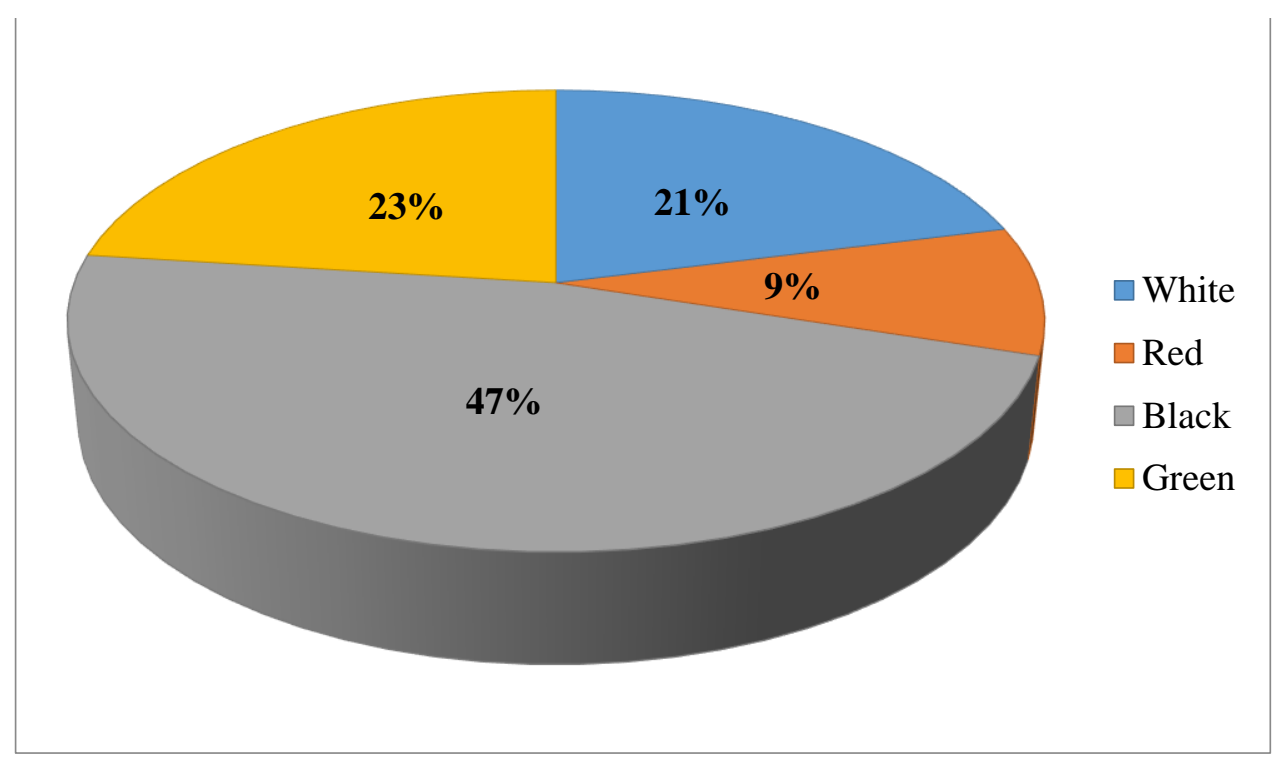

Figure 1. Frequency of the use of basic colouronyms in English journalistic discourse

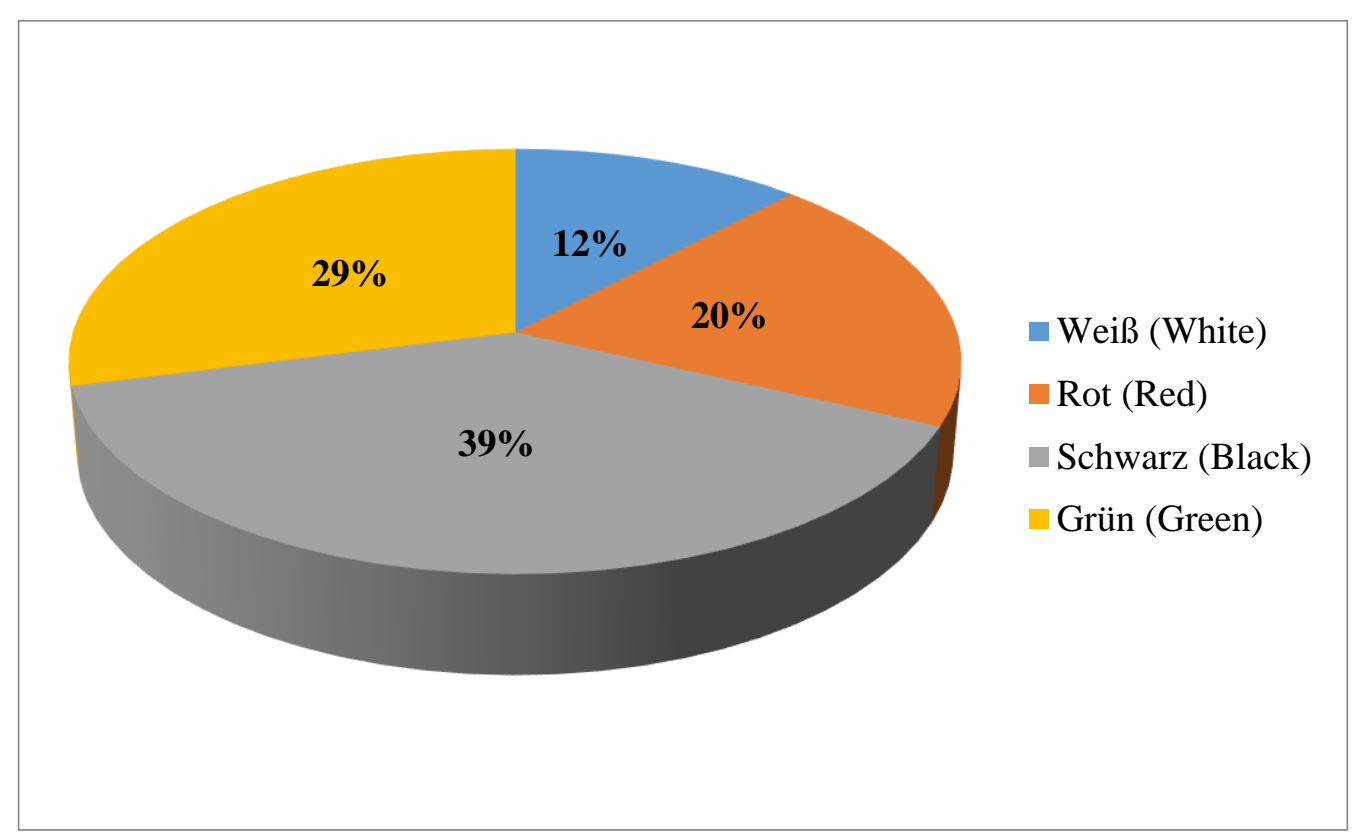

Figure 2. Frequency of the use of basic colouronyms in German journalistic discourse

Family words in Latin sordidus "dirty", sordis "dirt" allowed scholars to reconstruct the Indo-European platform *suordos meaning "black, dirty" (Pfeifer, 1997, p. 1257). It is noted in etymological dictionaries that the word schwarz is all-German, because it also exists in other Germanic languages: Goth -swarts, Old Saxon - swart, Old Iceland -svartr, Old English swear, Swedish -svart, Danish - sort, Dutch -zwaft, from which the German swartoz is reconstructed, in the Old Norse language sorti - dunkel (Online Etymology Dictionary, 2019).

Both in Old Germanic and in modern English and German, black evokes the idea of 
something illegal: black market (English) and der schwarze Markt (German). The plague epidemic is called the black death in both languages — the Black Death (English) and der SchwarzeTod (German). Accordingly, during mourning they wear black clothes: black-robed (English) - mourning dress, eine Frau in Schwarz (German) - a woman in black (dress), in mourning. Black is always associated with sadness, something unpleasant, negative: to paint something in black colors (English) $=$ schwarz malen — to represent something in "black color" (German). Black is also associated with something secret used against other people: a list of people suspected of something excluded from the general list - black list in English and die schwarze Liste - in German. Another identical expression is "white crow", "lousy sheep" (a person who is disapproved of for some reason): black sheep (English) and das schwarze Schaf (German).

In English, black is associated with blackmail, betrayal: blackmail - to squeeze money by intimidation and threats to publish unpleasant information about a person; to put the black on smb. - (coll.) to blackmail (someone) (Encyclopedia Britannica Online, 2018). The following units with the component "black" were found in the German language: der schwarze Peter - a scapegoat, ins Schwarzetreffen — to hit the bull's-eye (Phraseo, 2020). According to dictionaries, sometimes black loses its negative meaning and acquires a positive connotation: to be in the black (English) — to be profitable, to bring income (Encyclopedia Britannica Online, 2018), in den schwarzen Zahlensein (German) - to work making a profit, schwarze Zahlenschreiben - making a profit (Phraseo, 2020). This is because it was accepted to indicate losses in red, and income, profit — black in the financial statements.

Like in the English-language texts, the policy of black presidents is also assessed positively in German-language texts, and the racial question is also raised, as evidenced by the phrases die Geschichte der Sklaverei und des Rassismus: Versierter Pop für die Masse ... aufgelöst werden. Dass der Philo zum Beispiel ein Planet ist, dass soziale Netzwerke die Menschen vereinen, dass schwarze Präsidenten bessere Politik machen oder - ein paar Nummern kleiner - No Doubt so was wie Punkrock machen, ergo: so was wie Punbocker ... Um die Geschichte der Sklaverei und des Rassismus lebendig zu halten, brauch! es keine Statuen (tagesschau.de, 12.11.2016). Thus, the coloronym "black" prevails in both languages, usually in reports of racial issues. In the analysed texts in the selected languages the coloronym black/schwarz has lost its negative connotation and acquired new meanings.

For the other hand, white/weiß, when contrasted with dark, black evokes a joyful, optimistic mood, symbolises a bright, cheerful beginning. The English word "white" and the German "weiß" come from the Indo-European *kwei(t) - to shine, which is reserved in 
Sanskrit with inside the shape of sveta - (to be bright, white) (Pfeifer, 1997). This word was used in two meanings: color designation and figuratively, positive in relation to man. White color in the English and German language photograph of the arena is regularly related to kindness, honesty, joy, virtue, - this is largely due to the influence of Christian culture. When talking about a crystal honest person in accordance with moral norms, we use an ironic expression "whiter than white". The bride at a wedding is usually dressed in white ("white wedding"), because white traditionally symbolises the innocence and purity of the bride.

Let us note that in the English- and German-language journalistic discourse the analysed coloronym changes its positive connotation to neutral or negative. The most commonly used phrase in English- and German-language journalistic texts with weiß component are White House and Weißes Haus, respectively, to denote the US government. In English-language texts, the phrase White House takes an initial position in the sentence, emphasising the role of the US government in the events outlined in the message. For example, in the fragment Press secretary of White House Jen Psaki, performing on CBS This Morning from Cornwall, England, harassed that Biden's assembly with Vladimir Putin President of Russia subsequent week will awareness on "candid conversations." (edition.cnn., 10.06.2021).

In German-language journalistic texts, the phrase Weißes Haus is usually used in the middle of the sentence: US-Präsident Donald Trump Wurde nach Angaben des Weißen Hauses über den Test informiert ... (tagesschau.de,: 26. 08.2017); In einer Replik gen Bidens Vorwürfe verwies Trump im Weißen Sippe gen Bemühungen seiner Thron um eine Reorganisation des Strafjustizsystems, Investitionsprogramme wenn eine geringe Beschäftigungslosigkeit c/o Minderheiten im Vorhineinherweg jener Coronavirus-Pandemie (tagesschau.de, 15.07.2020). The coloronym white/weiß has a neutral connotation in the analysed fragments.

A number of phrases with the colouronym weiß to denote racial discrimination were found in German-language journalistic texts: weiße Rassisten, weiße Nationalisten, die weiße Vorherrschaft, as in the fragment Solche Beschwerden erhielten zuletzt Burundi und Irak Der UN-Menschenrechtsausschuss für die Beseitigung rassistischer Diskriminierung (Cerd) hat wegen der Demonstrationen weißer Rassisten in Charlottesville formell Beschwerde gegen die US-Regierung eingelegt (tagesschau.de, 13.05.2017). In this example, the coloronym weiß has a negative connotation.

It is believed that the adjective green/grün comes from the Indo-European root ghel (bright, yellow, green) (Pfeifer, 1997). Here you can see the connection with green plants and compare with a young person, talking about his/her youth, immaturity: the green years "young years" (Levytskyi, 2010, p. 223). Green is associated with youth, freedom, favourable 
circumstances (Witzel et al., 2016). This coloronym is used in English to mean inexperienced, young, naïve person: green hand - a beginner, an inexperienced person; grass green soldier q young soldier who has not yet been in a battle; to express jealousy: the green-eyed monster - jealousy, and its variants green eyed - very jealous, to look through green glasses — to be jealous; in the sense of a favourable set of circumstances: to give a green light — to give permission; in the sense of vigour, good physical condition: to keep the bones green - to maintain good health; in the sense of being able to grow plants: to have green fingers (Encyclopedia Britannica Online, 2018).

In German, green symbolises nature: bei Mutter Grün schlafen - to sleep in the open air; ins Grüne gehen - to take a walk out of town; eine Fahrt ins Grüne - outing; prosperity, good fortune: gen verknüpfen grünen Nebenlinie kommen — to make a profession, to succeed; Bureaucracy: vom grünen Tafel relativ Ergehen - to remedy bureaucratic troubles (Phraseo, 2020). The origin of the last phraseological unit with the coloronym grün is explained by the fact that the table of officials in Germany was upholstered in green cloth (Pfeifer, 1997). According to dictionaries, despite the approximately equal number of phrases with the coloronym green/grün in German and English, the range of meanings in which green is used in German is much wider than in English. Thus, the use of the component "green" in the meanings of material prosperity, bureaucracy, flattery is a feature of the German language and has no correspondence in English. The coincidence in the meanings of the phraseological units with the coloronym green/grün can be found in the units denoting the negative qualities of people (envy, anger), inexperience, naivety. Only in German grün denote nature as a whole, not just its part or property.

In English journalistic texts, the coloronym green is often found in conjunction with the phrase energy revolution, which is explained by the urgency of green energy in the modern world, for example in the title The green energy revolution is coming - with or without help from Washington (edition.cnn., 10.06.2021). Needless to say, that the coloronym green is also used in reports on environmental problems, as in an article entitled: World Environment Day: We must conserve and restore our ecosystems, for the sake of future generations (edition.cnn, 05.06.2021): Such investments not only save flora and fauna, but increasingly benefit ordinary people. The Protected Area Initiative I have launched to develop 15 model areas across Pakistan not only conserves over 2,818 square miles of land area, but also generates over 5,500 green jobs.

In the last two years, the phrase "green list" has been quite common in news reports, the frequency of its use is explained by the emergence of new realities, namely: the division of the 
country into green, yellow, orange and red zones. At the same time, this phrase is used in journalistic texts of any subject, because the pandemic has affected all spheres of human activity. For example, in a report on travel opportunities in Dubai in an article entitled “Traveling to Dubai during Covid-19: What you need to know before you go" we can find such coloronyms to indicate zoning: "The air border to neighboring Abu Dhabi reopened in December, though all arrivals other than those on the "greenlist" must currently isolate for 10 days. [..]. In January 2021, the UK placed the UAE on its travel "redlist".(edition.cnn, 10.06.2021).

Red/rot. English "red" and German "rot" comes from the Indo-European reudh /*roudh-/* rudh, which can be found in Western European (rote - Germ.,rojo - Spanish, rufus - Latin). Coloronyms red and rot are used in English and German not only to mean "red", but also to describe human hair and animal hair: red-haired, red fox. Red is associated with fire, war, energy, aggression, danger, impulse, passion, love, joy, health, physical strength and youth, and is also related to blood. English phrase "(to take somebody) red-handed" literature's mean is "to catch someone with hands like a blood, that is, with hands stained with blood." The expression first appears in W. Scott's novel Ivanhoe (1819) (Online Etymology Dictionary, 2019).

In German, the following symbolic meanings of the coloronym "red" are realised, which have a negative meaning, for example: Es war ihm rot imVoraus den Augen - rage blinded him; sich die Augen rot weinen - to red eyes from crying; den roten Hahn aufsDachsetzen - to set fire to something, arrange a fire; blush as red as a beetroot - rot wieeingekochter Krebs werden (red is associated with embarrassment, shame or resentment); to red as a turkey-cock - blutrot warden (meaning with anger or irritation).

The analysed coloronym is also used in texts about the environment, nature, as in the text entitled 3yearsin the past, abigalgae bloom in Florida killed 2,000 lots of marine existence. It's threatening again (version.cnn, 04.06.2021): "I believe pink tide goes to be right herewith us every summer time," said Rafael Rios, who has owned a constitution fishing boat out of St. Petersburg for 15 years but said he has been fishing the waters of Tampa Bay for 30 years, "there is years we don't see any. There is years we see a lot greater." Like English texts, the German coloronym rot is used in texts on epidemic zoning, such as in the title EinViertel der Italiener in "roter Zone" (tagesschau.de, 05.11.2020).

The coloronym rot as a component of phraseological units is found in economic texts, for example, in the titles Rote ZahlenbeiGaleriaKarstadtKaufhof (tagesschau.de, 19.12.2019); Porsche schreibt rote Zahlen (tagesschau.de, 10.08.2020); Continental tief in den rotenZahlen 
(tagesschau.de, 21.10.2020). In the given examples, phraseological units with the coloronym rot are used to denote losses in the economic sphere: rote Zahlen - red numbers, it is about the debt, rote Zahleschreiben - to write a deficit in the balance sheet, in den rotenZahlenliegen to be in deficit (Pfeifer, 1997). The coloronym rot in the composition of these phraseological units is explained by the tradition of merchants who recorded losses and shortages in red ink.

\section{Discussion}

The evolution of coloronyms in English and German is marked by the absence of a color attribute at the stage of their development, as evidenced by etymological dictionaries (Online Etymology Dictionary, 2019), only red and black had a color attribute that allows considering them the oldest colors (Scheurmann \& Karliczek, 2017). The study of coloronyms in English and German journalistic texts found that coloronyms change their primary meaning, often to the opposite, depending on the units with which coloronyms are combined in the text. We believe that the theory of Berlin and Kay (1969), in which black and white are the basic colors, cannot be applied to journalistic texts, because the results of our analysis showed that only black can be called basic in modern English and German linguistic cultures. Instead, white is underused in the texts of journalistic discourse, because it, according to scholars (Spillmann, 2018), is perceived neutrally, and therefore cannot be information-rich. Künzer, Zinke and Hofinger (2018) argue that even the interaction of black and white is perceived neutrally. At the same time, the analysis of German journalistic texts showed that the coloronym weiß/white has a negative connotation in combination with nouns to denote racism, so it cannot be considered purely neutral.

We have a different opinion on the point that black and white are at the core of the color picture of the world of both languages, as evidenced by modern scholars (Claire, 2017). Besides, we cannot say that red belongs to the basic colors, as Kim et al. (2019) indicated. In our opinion, the color picture of native speakers of different languages is in constant dynamics, so when studying the qualitative features of coloronyms, it is impossible to ignore their quantitative indicators, which are manifested in the frequency of use in journalistic texts. Frequency determination is a very popular method of lexicostatistics (Dyszak, 2014), because it helps to separate more popular coloronyms from less popular ones, to make their rating, shown in Figure 1 and Figure 2 of this study.

The study showed that the linguistic and color picture of the world of English and German changes according to political, economic and social events in a particular society and in the world as a whole. In English journalistic texts, green is relevant after black, while green 
and red share this position in German. We agree that green is associated with safety and rescue (Scheurmann \& Karliczek, 2017) and red — with danger (Künzer et al., 2018). This fact proves, among other things, the use of these coloronyms in the texts of English- and German-language news about the zoning of countries during the pandemic. In addition, the predominance of the coloronym to denote green in English and German journalistic texts is explained by the large number of reports on ecology. In German texts, the predominance of the coloronym rot/red, in addition to the zoning of countries, is due to the significant number of reports of damage to various corporations caused by the pandemic.

There is no doubt that coloronyms perform a text-creating function in journalistic texts, which is the ability to form a text, creating coherent, multifaceted images (Waszakowa, 2015), allows coloronyms to create a "fabric" of the text, forming a powerful associative subtext. All this makes coloronyms unique linguistic and cultural signs, indispensable in the creation of journalistic texts.

The theoretical significance of the work is the in-depth study of English and German coloronyms with the involvement of contextual material - modern news English and German texts. The research allows to theoretically comprehend the essence of color units of language, to understand the diversity of their semantics and pragmatics, as well as to trace the peculiarities of functioning and to determine the boundaries of lexical-semantic microfields. It reveals the mechanisms of formation of language associations. Observations and conclusions of this work can be used in further theoretical study of both English and German, as well as coloronyms of other languages and linguistic features of news texts. The obtained results are a contribution to such branches of German studies as lexicology (Lexical Semantics section), phraseology, linguistic stylistics of English and German languages, sociolinguistics, theory of connotation. The contribution to lexicology is to replenish the vocabulary with composites and phraseology with a color component. Phraseology is supplemented by conclusions and generalizations about paradigmatic connections between constant inversions with a color component. For linguistic stylistics of theoretical value, it is important to clarify the peculiarities of the functioning of coloronyms in English- and German-language journalism. For the theory of connotation, our observations on the formation of new units with estimated values are important. The contribution to sociolinguistics is to reveal the influence of the phenomenon of color on the formation of the modern vocabulary of English and German. This contribution can be extrapolated to the relevant fields of general and comparative historical linguistics.

The practical significance of the study is determined by the fact that its results can be used in the teaching of courses in lexicology and stylistics of English and German languages, 
general linguistics, in the development and implementation of elective courses; in educational and methodical work when preparing educational and methodical manuals on research problems; in lexicographic practice when compiling explanatory printed and electronic dictionaries, dictionaries of frequency of coloronyms for the needs of corpus linguistics; special courses in semantics, pragmatics, psycholinguistics, ethnolinguistics, stylistics, etc. in higher educational institutions. The study reveals the practical dominants of their use and ways of real impact on recipients through the pragmatic aspect of the functioning of coloronyms.

\section{Conclusions}

The analysis of English and German journalistic texts proved that coloronyms are used in regular phrases, which usually denote human activity. The meaning of coloronyms in the analyzed journalistic texts does not always coincide with the meaning recorded in lexicographical sources, because in a journalistic text it depends on the context that determines the nature of connotation. It is established that coloronyms with positive meanings recorded in dictionaries change them in journalistic texts to negative ones and vice versa. The following thematic groups were singled out in the analyzed English and German messages, in which basic coloronyms were used: politics, activities, finance, epidemic, environment. Each group differs in the composition of coloronyms.

The core of the color picture of the world of English and German is represented by coloronyms to denote black. Green is added to it in English, while it's complimented by green and red in German, which reflects the modern picture of the world of speakers of these languages. The semantic typology of coloronyms in both languages differs due to the different picture of the world of English and German speakers, but events that unite the whole world may for a positive time frame actualize the prevalence of the same coloronyms in journalistic texts, such as red and green for epidemic zones. The obtained research results can be used in courses in sociolinguistics, intercultural communication, history of a foreign language, and can also be useful for students of the Faculty of Journalism. The prospects for further research include a comparative study of coloronyms in Germanic and Slavic languages.

\section{References}

Antipova, A. (2020). German phraseology with a colorative component: structure, semantics, translation. Master thesis. Sumy State University. https://essuir.sumdu.edu.ua/bitstreamdownload/123456789/81830/1/Antipova_mag_rob.pdf

Berlin, B., \& Kay, P. (1969). Basic Color Terms: Their Universality and Evolution. Oakland: 
University of California Press.

Boerboom, P., \& Proetel, T. (2018). Color: material and effect - perceive and experiment. Bern: Haupt Gestalten.

Chernetska, N. (2018). Colour names in the structure of phraseological units in Spanish and Ukrainian. Studia Philolologica, 10, 29-33. https://doi.org/10.28925/23112425.2018.10.4

Claire, K. St. (2017). The world of colors. Prague: Tempo.

Davies, I. (2005). Colour terms. In A. Cruse, F. Hundsnurscher, M. Job, \& P. Rolf Lutzeier (eds.), Lexikologie, Lexicology (pp. 1542-15-48). Berlin: De Gruyter Mouton.

Duden. (2020). Idioms: dictionary of German idioms. Zürich: Dudenverlag.

Dyszak, A. S. (2014). The language exponents of colors in the interwar (1918-1939) poems by Jan Lechoń. Studia językoznawcze. Synchroniczne i diachroniczne aspekty badań polszczyzny, 13, 67-90. https://wnus.edu.pl/sj/en/issue/787/article/13729/

Encyclopedia Britannica Online. (2018). http://www.search.eb.com/eb/article?eu=117710

Gage, J. (2011). The language of colors: the change in the meaning of color in the history of science and art. Leipzig: Verlag Seemann E.A.

Gramazio, C. C., Laidlaw, D. H., \& Schloss, K. B. (2017). Colorgorical: Creating discriminable and preferable color palettes for information visualization. IEEE Transactions on Visualization and Computer Graphics. https://gramaz.io/pdf/gramazio-2016-ccd.pdf

Herasymenko, I. A. (2012). The problem of structural and lexical-semantic organization of colorants in the Russian language. Movoznavstvo, 1, 49-54. https://movoznavstvo.org.ua/arkhiv-zhurnalu/vsi-nomera-zhurnalu/2012-1-sichenlyutij/219-i-a-gerasimenko-problema-strukturnoji-ta-leksiko-semantichnojiorganizatsiji-kolorativiv-u-rosijskij-movi.html

Holovanevska, K. (2018). English phraseology-coloronyms and their reproduction in the Ukrainian translation. Master thesis. Zaporizhzhya National Technical University. http://eir.zp.edu.ua/bitstream/123456789/3964/1/Holovanevska_English.pdf

Kim, Y., Thayer, K., Gorsky, G. S., \& Heer, J. (2019). Color names across languages: Salient colors and term translation in multilingual color naming models. Eurographics Proceedings. $\quad$ https://idl.cs.washington.edu/files/2019-MultiLingualColorNamesEuroVis.pdf

Kulpina, V. (2007). The system of color designations of the Russian language in historical lighting. In A. Vasilevich (Ed.), Names of color in Indo-European languages: a systematic and historical analysis (pp. 126-184). Moscow: KomKniga.

Künzer, L., Zinke, R., \& Hofinger, G. (2018). Dynamic Guidance by Colored Running Lights and Affordance: Route Choices of Adults and Older Children. Proceedings from the 9th International Conference on Pedestrian and Evacuation Dynamics (PED2018) (pp.

Sweden. 
ttps://www.researchgate.net/publication/340291786_Dynamic_Guidance_by_Colore d_Running_Lights_and_Affordance_Route_Choices_of_Adults_and_Older_Children

Lukashenko, E. (2011). Functional-nominative potential of color designations in the context of the cognitive paradigm (based on the English language). $\mathrm{PhD}$ abstract thesis. $\mathrm{O} . \mathrm{N}$. Dobrolyubov Nizhny Novgorod State Linguistic University. Retrieved from https://www.dissercat.com/content/funktsionalno-nominativnyi-potentsialtsvetooboznachenii-v-kontekste-kognitivnoi-paradigmy

Magnus, H. (1980). Investigation into the color sense of primitive peoples. Leipzig: Max Hueber.

Normanskaya, Y. (2005). Genesis and development of color designation systems in ancient Indo-European languages. Moscow: IY RAN.

Nufer, G., \& Wenk, V. (2017). Wirkungen von Farben im Marketing. Reutlingen Working Papers on Marketing \& Management, 2. https://www.esbbusinessschool.de/fileadmin/user_upload/Fakultaet_ESB/Forschung/ Publikationen/Diskussionsbeitraege_zu_Marketing_Management/Reutlinger_Diskuss ionsbeitrag_2017_-_2.pdf

Online Etymology Dictionary. (2019). Retrieved from http://www.etymonline.com.

Pfeifer, W. (1997). Etymological dictionary of German. München: Deutscher Taschenbuch Verlag GmbH.

Phraseo. (2020). Sayings and proverbs with colors. http://www.phraseo.de/sammlung/farben/

Radonjić, A., \& Brainard, D. H. (2016). The nature of instructional effects in color constancy. Journal of Experimental Psychology: Human Perception and Performance, 42 (6), 847-865. https://doi.org/10.1037/xhp0000184

Scheurmann, K., \& Karliczek, A. (2017). Talking fabric color. Contributions from science, art and society. Köln: Böhlau.

Serov, N. (2004). The color of culture: psychology, cultural studies, physiology. St-Peterburg: Rech.

Shaitan, V. (2018). Principles and features of translation of phraseology with the component "coloronym" in modern Greek, English and Ukrainian. Vseosvita. https://vseosvita.ua/library/principi-i-osoblivosti-perekladu-frazeologizmiv-izkomponentom-koloronim-v-novogreckij-anglijskij-ta-ukrainskij-movah-50421.html

Spillmann, W. (2018). Aemilius Müller - Aesthetics of Color. Cham: Chronos.

Talapina, M. (2008). Comparative study of Russian and English adjectives "white / black" and "white / black" in the cognitive-discursive aspect. $\mathrm{PhD}$ Dissertation. Institute of Scientific Information on Social Sciences. https://www.dissercat.com/content/sopostavitelnoe-issledovanie-russkikh-iangliiskikh-prilagatelnykh-belyichernyi-i-whiteblack 
Tikan, Y., \& Lopianetska, R. (2020). Functioning of phraseological units with a coloristic component in English media texts. Advanced Linguistics, 5, 33-40. https://doi.org/10.20535/2617-5339.2020.5.205156

Vasilevich, A. (2007). Etymology of color names as a mirror of national and cultural consciousness. In A. Vasilevich (Ed.), Names of color in Indo-European languages: a systematic and historical analysis (pp. 9-28). Moscow: KomKniga.

Volkova, T. (2019). Phraseologisms-coloronyms in modern English linguistic culture. In T. A. Kokonova (Ed.), Romano-Germanic languages in the modern intercultural space: coll. conference materials (pp. 29-31). Starobilsk: Publishing House of Taras Shevchenko Luhansk National University.

Waszakowa, K. (2015). Pragmatics of word-formation action (Continuation of Maria Honowska's thought on the techniques of becoming word-formation forms). LingVaria, $\quad$ 1(19), 99-108. http://www.lingvaria.polonistyka.uj.edu.pl/documents/5768825/51e1a506-60e849e6-abf7-e5e4fba51048

Witzel, C., O'Regan, J. K., \&Rothen, N. (2016). Synaesthetic colour experiences are perceptually real. Proceedings from the 9th Conference of the United Kingdom Synaesthesia Association - Synaesthesia and cross-modal perception. Trinity College, Dublin, Ireland. https://boris.unibe.ch/id/eprint/85890 